\title{
BERPIKIR GEOMETRI LEVEL VISUALISASI SISWA SEKOLAH MENENGAH PERTAMA MELALUI TOPIK SEGIEMPAT MENURUT TEORI VAN HIELE
}

\author{
Harun Abdul Rohman ${ }^{1 *}$ iD, Dadang Juandi ${ }^{2}$, , Al Jupri ${ }^{3}$ \\ 1,2,3 Universitas Pendidikan Indonesia \\ ${ }^{1 *}$ harun88pltg@upi.edu, 2Dadang.Juandi@upi.edu, ${ }^{3}$ aljupri@upi.edu
}

\author{
Received: August 27, 2021 \\ Revised: September 15, 2021 \\ Accepted: October 2, 2021
}

\begin{abstract}
:
This research aims to describe the level of geometric thinking and geometric thinking processes of Junior High School students according to van Hiele's level of thinking on the topic of quadrilaterals. The qualitative approach is the research method used in this study through a case study method by testing the Van Hiele Geometry Test (VHGT) which was adapted from Usiskin's CDASSG and conducting interviews about the thinking process in the form of identifying, defining, and classifying which was adapted from the interview guide of Burger and Shaughnessy (1986). The subjects of this study were 297 grade VII and VIII students from two schools located in the Lembang sub-district. The results of the VHGT test showed that there were 81 students counting level 0 (visualization). The results showed that the students of class VII and VIII level 0 were as follows: 1) students were able to recognize the types of quadrangle but still affected by the prototype, 2) students were not able to classify quadrilaterals, and 3) overall description of the geometric thinking process level 0 in the form of identifying, defining, and classifying aspects according to van Hiele's thinking characteristics in general.
\end{abstract}

Keywords: van Hiele Thinking Level, Geometric Thinking Process, Quadrilaterals.

How to Cite: Rohman, H. A., Junaidi, D., \& Jupri, A. (2021). Berpikir Geometri Level Visualisasi Siswa Sekolah Menengah Pertama Melalui Topik Segiempat Menurut Teori Van Hiele. Alifmatika: Jurnal $\begin{array}{llll}\text { Pendidikan dan } & \text { Pembelajaran } & \text { 133-144. }\end{array}$ https://doi.org/10.35316/alifmatika.2021.v3i2.133-144

\section{PENDAHULUAN}

Studi pendahuluan telah dilakukan pada kelas VIII dengan memberikan tes berupa soal yang diadaptasi dari Fischbein (Fischbein, 1993) untuk melihat pemahaman mengenai konsep definisi dan mengidentifikasigambar segiempat. Siswa diberikan tes soal mengenai kemampuan memahami konsep definisi dari jajargenjang dan mengidentifikasi gambar-gambar yang termasuk ke dalam jajargenjang sesuai dengan definisi yang mereka pahami. Hasil tes seperti pada gambar 1, semua dari kelas VIII sekolah pertama yang berjumlah 60 orang hanya memilih gambar 1 bagian b saja yang termasuk jajargenjang, baik yang mampu mendefinisikan dengan benar maupun mendefinisikan dengan keliru. Hasil tes seperti pada gambar 1 memperlihatkan bahwa siswa mampu mendefinisikan jajargenjang sebagai bangun datar yang mempunyai dua sisi yang saling 
berhadapan dan sama panjang, namun siswa tersebut hanya mampu mengidentifikasi satu gambar jajargenjang. Padahal gambar-gambar lainnya, yaitu $c$, $d$, dan $\mathrm{f}$ yang sesuai dengan definisi yang mereka ungkapkan yaitu bangun datar yang memiliki dua pasang saling berhadapan dan sama panjang tidak dipilih oleh siswa sebagai jajargenjang. Hasil pekerjaan siswa pada gambar 1 memberikan gambaran bahwa siswa tidak memahami definisi yang dituliskan oleh dirinya sendiri.

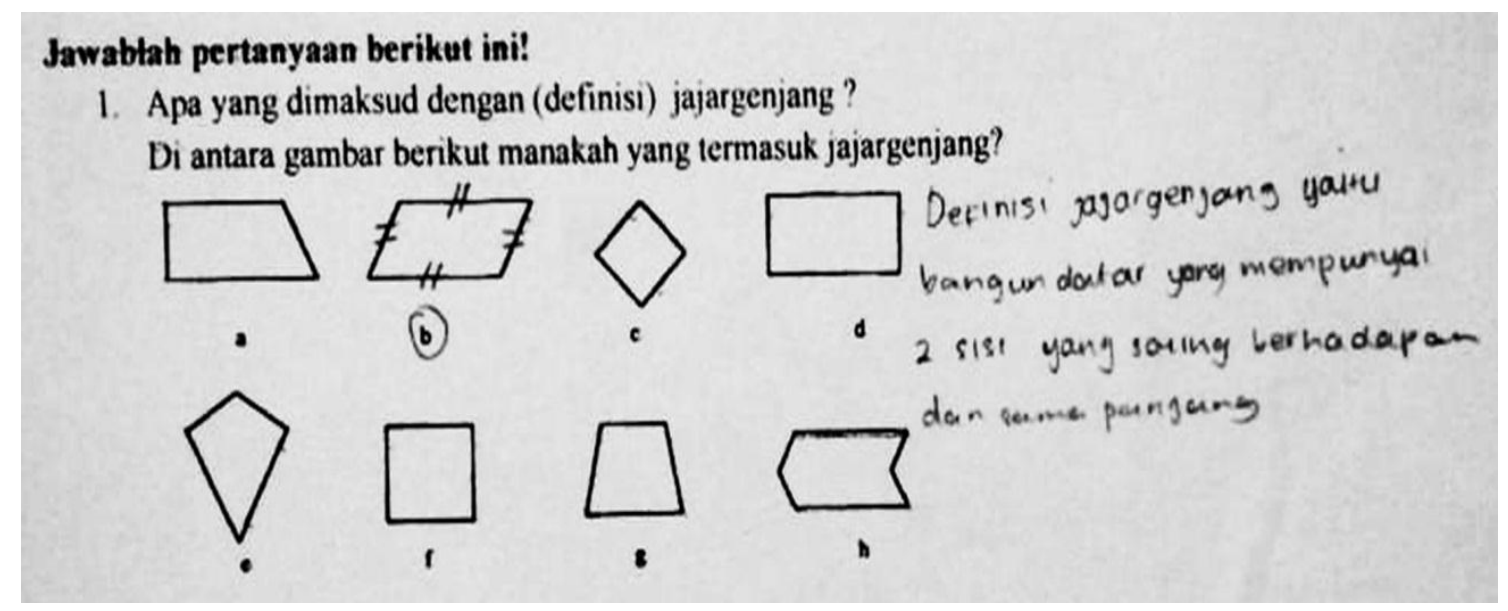

Gambar 1. Hasil Pekerjaan Siswa

Hasil-hasil penelitian sebelumnya menemukan bahwa banyak siswa yang mengalami kesulitan dalam mengklasifikasikan segiempat karena kesulitan dalam memahami definisi (Burger \& Shaughnessy, 1986; M De Villiers, 1994; Monaghan, 2000). Hasil penelitian Burger dan Shaugnessy (Burger \& Shaughnessy, 1986) menemukan bahwa kesulitan dalam mendefinisikan dan mengklasifikasikan segiempat terjadi pada siswa level 0 dan 1 . Kesulitan siswa dalam memahami definisi juga dipengaruhi oleh gambaran mereka sendiri mengenai suatu bentuk jenis segiempat. Sehingga definisi mereka tidak formal dan memengaruhi mereka dalam mengklasifikasikannya (Burger \& Shaughnessy, 1986; M De Villiers, 1994; Fujita \& Jones, 2007; Monaghan, 2000). Hasil penelitian Fujita (Fujita, 2012:16) menemukan bahwa banyak pelajar mendefinisikan persegi panjang sebagai segiempat yang mempunyai dua sisi panjang dan dua sisi pendek. Definisi persegi panjang ini memberikan alasan siswa tidak menggolongkan persegi termasuk persegi panjang, karena persegi mempunyai empat sisi yang sama panjang. Hasil penelitian lainnya menunjukkan pengaruh prototipe lebih dominan dari pada definisi dalam membentuk pemahaman konsep segiempat (Fuys et al., 1988; Hershkowitz, 1998; Mariotti, 1992; Muhassanah, Nur'aini., Sujadi, Imam., 2014; Sulistiowati, D. L., Herman, T., \& Jupri, 2018; Vinner, S., \& Hershkowitz, 1980). Pengaruh prototipe menyebabkan siswa kesulitan dalam mengidentifikasi jenis bangun datar. Seperti yang dilaporkan dalam penelitian sebelumnya (Fujita \& Jones, 2007; Fujita, 2012; Monaghan, 2000; Okazaki, M., \& Fujita, 2007) menemukan sebuah bentuk segiempat yang mengalami orientasi dari contoh yang diberikan dapat menyulitkan siswa dalam mengidentifikasi jenis bentuk tersebut.

Alifmatika: Jurnal Pendidikan dan Pembelajaran Matematika, Desember 2021, Vol. 3, No. 2 
Penelitian-penelitian lainnya juga menggambarkan perkembangan konsep geometri dalam level berpikir van Hiele meliputi keterkaitan antara kemampuan mendefinisikan, mengidentifikasi, mengklasifikasi, dan membuktikan terdapat dalam level berpikir van Hiele dalam menggambarkan perkembangan konsep geometri (Crowley, 1987; Fuys et al., 1988; Gutiérrez, Angel., Jaime, Adela ., \& Fortuny, 1991; Ho, 2003). Menurut De Villiers (Gutiérrez \& Jaime, 1998) mengategorikan pemikiran geometri yang sesuai dengan teori van Hiele yaitu: 1) mengenal dan menunjukan jenis-jenis bentuk geometri; 2) menggunakan dan memahami terminologi;3) mendeskripsikan secara verbal sifat-sifat dari berbagai bentuk geometri; 4) mengklasifikasikan bentuk geometri; dan 5) berpikir deduktif. Level berpikir van Hiele terbagi ke dalam 5 tahapan yang saling simultan tiap tahapanya. Penjelasan masing-masing dari tahapan-tahapan level van Hiele adalah sebagai berikut (Crowley, 1987; van De Walle, J. A., Karp, K. S., \& Bay-Williams, 2016): 1) Tahapanya dimulai dari level 0 (visualisasi) yaitu siswa mengenal bentuk sebagai sesuatu yang berada di sekeliling mereka dan berdasarkan yang tampak dilihat oleh diri sendiri dan seringkali membandingkannya dengan prototipe yang telah mereka kenal; 2) Level 1 (analisis) yaitu siswa mampu menentukan sifat-sifat dari bangun datar berdasarkan observasi, pengukuran, dan menggambar; 3) Level 2 (deduksi informal) yaitu siswa mampu memahami hubungan antara sifat-sifat antar bangun datar berdasarkan definisi abstrak; 4) level 3 (deduksi) yaitu siswa mampu membuat pembuktian, memahami penggunaan aksioma dan definisi; 5) level 4 (rigor) yaitu siswa memahami aspek formal deduksi dan memahami postulat atau dalil, aksioma, dan geometri nonEuclid.

Peneliti mengambil istilah proses berpikir sebagai gambaran kegiatan aktivitas mental yang melibatkan pemahaman konsep. Pemahaman konsep dalam penelitian ini meliputi kemampuan siswa dalam mengidentifikasi, mendefinisikan, mengklasifikasikan, dan membuktikan. Ketiga aktivitas mental ini dapat dibimbing dan diarahkan untuk menentukan dan membangun konsep dari setiap bentuk bangun datar (Linda et al., 2020). Salah satu cara mengetahui pemahaman konsep adalah dengan memberikan persoalan pada siswa. Ketika siswa diberikan suatu masalah matematika maka siswa akan mengolah informasi yang ada dan memanggil kembali informasi yang tersimpan dalam memori jangka panjang untuk memecahkan masalah. Hal ini sejalan dengan pendapat Rahmat (Rahmat, 2019) yang menyatakan bahwa proses berpikir adalah proses yang dimulai dari penemuan informasi (dari luar atau diri siswa), pengolahan, penyimpanan dan memanggil kembali informasi itu dari ingatan siswa. Selain itu sejalan juga dengan pendapat Suryabrata (Tirtaprimasyah, H. P. S., \& Susanto, 2015) mengemukakan bahwa proses berpikir merupakan proses dinamis yang dapat melukiskan menurut proses atau jalannya.

Berdasarkan temuan-temuan sebelumnya dan studi pendahuluan mengenai kelemahan siswa dalam mengidentifikasi, mendefinisikan, dan mengklasifikasikan serta teori van Hiele yang komprehensif mengenai gambaran perkembangan konsep geometri tiap level berpikir, penelitian ini berusaha mendeskripsikan bagaimana proses berpikir siswa level 0 pada materi segiempat. Deskripsi proses berpikir siswa sendiri peneliti peroleh dari pedoman wawancara Burger dan Shaughnessy (Burger \& Shaughnessy, 1986). Pedoman wawancara ini peneliti

Alifmatika: Jurnal Pendidikan dan Pembelajaran Matematika, Desember 2021, Vol. 3, No. 2 
ambil karena sesuai dalam menggambarkan proses berpikir geometri siswa. Setelah diketahui proses berpikir geometri siswa di kedua sekolah tersebut, hasil penelitian ini dapat dijadikan referensi untuk guru dalam mengajarkan geometri pada siswa level 0 dengan memperhatikan aspek proses berpikir agar siswa mampu memahami definisi, mengidentifikasi, dan mengklasifikasikan sesuai konsep segiempat yang benar.

\section{METODE PENELITIAN}

Jenis penelitian kualitatif dengan menggunakan metode studi kasus.Teknik pengumpulan data dilakukan secara triangulasi (gabungan), analisis data bersifat kualitatif, dan hasil penelitian berupa generalisasi dari kasus-kasus spesifik. Penelitian ini berusaha untuk mendeskripsikan secara jelas dan berurutan terhadap suatu masalah yang telah ditentukan sebelum peneliti turun ke lapangan. Selain itu peneliti tidak melakukan perlakuan khusus dan hipotesis sebagai petunjuk penelitian. Metode ini berusaha mendeskripsikan tingkat berpikir geometri siswa dan proses berpikir geometri siswa pada topik segiempat untuk setiap level berpikir van Hielekelas VII dan VIII pada dua sekolah menengah pertama di kecamatan Lembang.Sebanyak 297 siswa dari kelas VII dan kelas VIII melakukan tes VHGT di dua sekolah yang berada di Lembang dengan alasan untuk melihat perbedaan proses berpikir geometri siswa level 0 di setiap jenjang kelasnya.

Pengumpulan data dilakukan dengan menggunakan tes tulis dan wawancara. Tes tulis pada penelitian ini menggunakan van Hiele geometry test (VHGT) yang terdiri dari 25 soal pilihan ganda hasil terjemahan dari Tri Nopriana (Nopriana, 2013) yang sudah teruji kevalidan dan realibilitasnya untuk mengetahui tingkatan berpikir geometri siswa. Hasil tes VHGT diperoleh 81 siswa termasuk level 0 yaitu siswa yang hanya mampu menjawab skor minimal tiga dari lima soal pada subtes 1 , sedangkan subtes lainnya kurang dari tiga soal terjawab. Hasil tes siswa level 0 dilanjutkan dengan analisis soal dan analisis jawaban per-soal yang sulit dijawab oleh siswa. Untuk menindaklanjuti analisis tes VHGT, peneliti juga melanjutkan wawancara yang berpedoman pada Final Report "Assesing Children's Intelectual Growh in Geometry" oleh Burger dan Shaughnessy (Burger \& Shaughnessy, 1986) pada materi segiempat. Wawancara dilakukan dua orang siswa kelas VII dan VIII yang masing-masing memiliki skor 3 (kategori rendah) dan 4 (kategori sedang) dari skor maksimal 5 soal yang terjawab untuk tes level 0. Siswa level 0 yang bersedia diwawancarai dari kelas tujuh sekolah kedua yaitu 7S0R2 dan siswa 7S0S2 dengan masing-masing kategori level 0 rendah dan level 0 sedang, sedangkan dari kelas VIII terdapat satu orang siswa yaitu 8S0R1 kategori level 0 sedang dan satu oramg dari sekolah kedua yaitu siswa 8S0S2 dengan kategori sedang. Wawancara ini terdiri diawali dengan tes tulis seperti yang tampak pada gambar 4.(a) yaitu mendaftarkan jenis-jenis segiempat berdasarkan gambar yang diberikan soal yang kemudian dilanjutkan dengan wawancara mengenai cara mengidentifikasi, mendefinisikan, dan mengklasifikasikan segiempat berdasarkan hasil tes tulis. Sesuai pedoman wawancara, level 0 tidak diwawancarai mengenai pembuktian. Hal ini merujuk pada teori van Hiele bahwa level 0 belum mampu membuktikan. Terakhir peneliti memberikan kesimpulan berdasarkan hasil

Alifmatika: Jurnal Pendidikan dan Pembelajaran Matematika, Desember 2021, Vol. 3, No. 2 
analisis tes tulis jawaban VHGT dan wawancara mengenai proses berpikir siswa level 0.

\section{HASIL DAN PEMBAHASAN}

Hasil tes VHGT menunjukan bahwa terdapat 81 siswa termasuk level 0 (visualisasi) Siswa level 0 adalah mereka yang mempunyai skor maksimal 3 dari 25 soal yang benar berdasarkan pedoman penskoran van Hiele. Hasil analisis data tes geometri siswa (VHGT) level 0, seperti yang terlihat pada gambar 1, baik kelas VII dan kelas VIII memiliki skor lebih dari 80\% untuk soal nomor 1, 2, dan 3, sedangkan soal nomor 4 dan 5 kurang dari 50\%. Siswa paling banyak kesalahan pada soal nomor 4 dan 5 tes geometri van Hielemengunjukkan bahwa siswa kesulitan dalam menentukan persegi dan jajargenjang di antara bangun datar segiempat jenis lainnya.

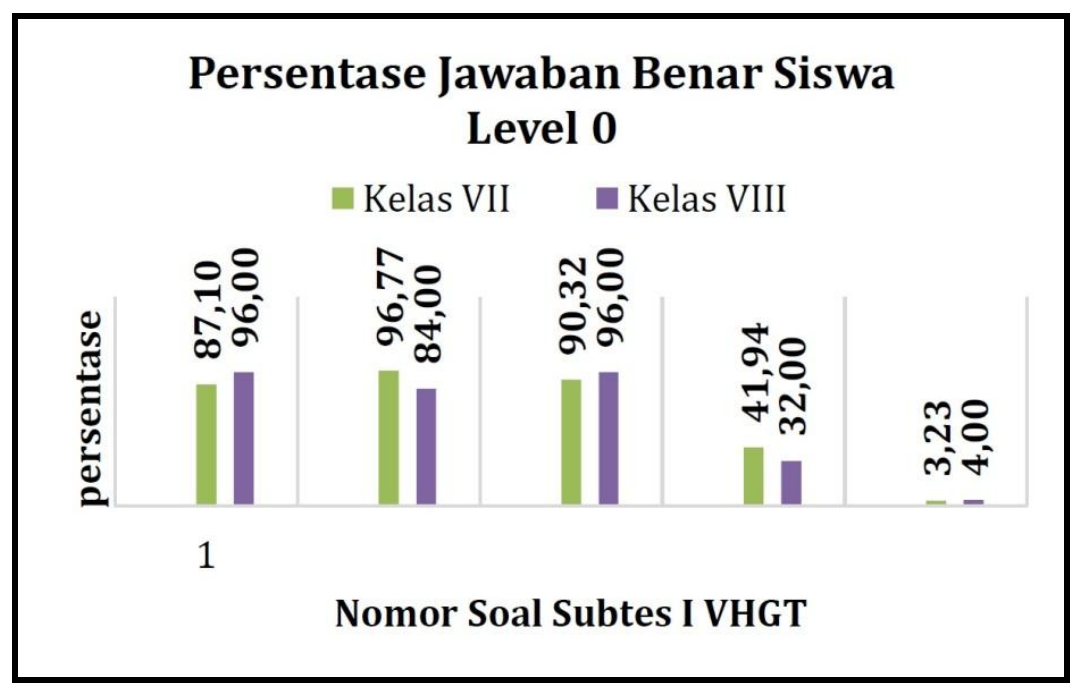

Gambar 2. Persentase Jawaban Benar Level 0 pada Subtes I VHGT

Hasil analisis jawaban siswa soal nomor 4 menunjukan bahwa siswa dalam menentukan persegi masih terpengaruh oleh orientasi persegi. Hal ini bisa terlihat dari karang dari 42\% siswa memilih pilihan yang benar yaitu pilihan b yang menunjukan gambar persegi yang mengalami orientasi. Selain itu sedikitnya siswa yang memilih pilihan pilihan c $(6,45 \%$ dan $2 \%)$, d (9,68\%) dan $4 \%)$, dan e $(6,45 \%$ dan $12 \%$ ) menunjukan bahwa siswa sudah mampu membedakan persegi dengan yang lainnya, namun karena pengaruh orientasi sehingga yang tidak memilih pilihan c, d, dan e tersebar paling banyak pada pilihan a (tidak satupun yang merupakan persegi). Hasil analisis jawaban soal nomor 5 menunjukan siswa tidak terpengaruh orientasi dan tidak mampu mengklasfikasikan jajargenjang. Hal ini dapat terlihat dengan persentase terbesar untuk pilihan gambar J (jajargenjang tampak sepasang garis sejajar tampak horizontal) dan gambar $\mathrm{M}$ (jajargenjang mengalami orientasi) lebih besar dengan persentase lainnya. Namun, dengan melihat sedikitnya yang memilih pilihan e (semuanya merupakan jajargenjang) yaitu pilihan yang benar, siswa bisa dikatakan siswa tidak mampu menggolongkan bahwa gambar L (belah ketupat) termasuk jajargenjang. Hal tersebut karena siswa tidak mampu mengklasifikasikan jajargenjang. Kesulitan ini juga ditemukan pada

Alifmatika: Jurnal Pendidikan dan Pembelajaran Matematika, Desember 2021, Vol. 3, No. 2 
penelitian-penelitian yang telah dilakukan (Michael De Villiers, 1996; Hershkowitz, 1998; Monaghan, 2000; Usiskin, 2008). Hasil persentase jawaban siswa nomor 4 dan 5 seperti tampak pada gambar 2 di bawah ini.

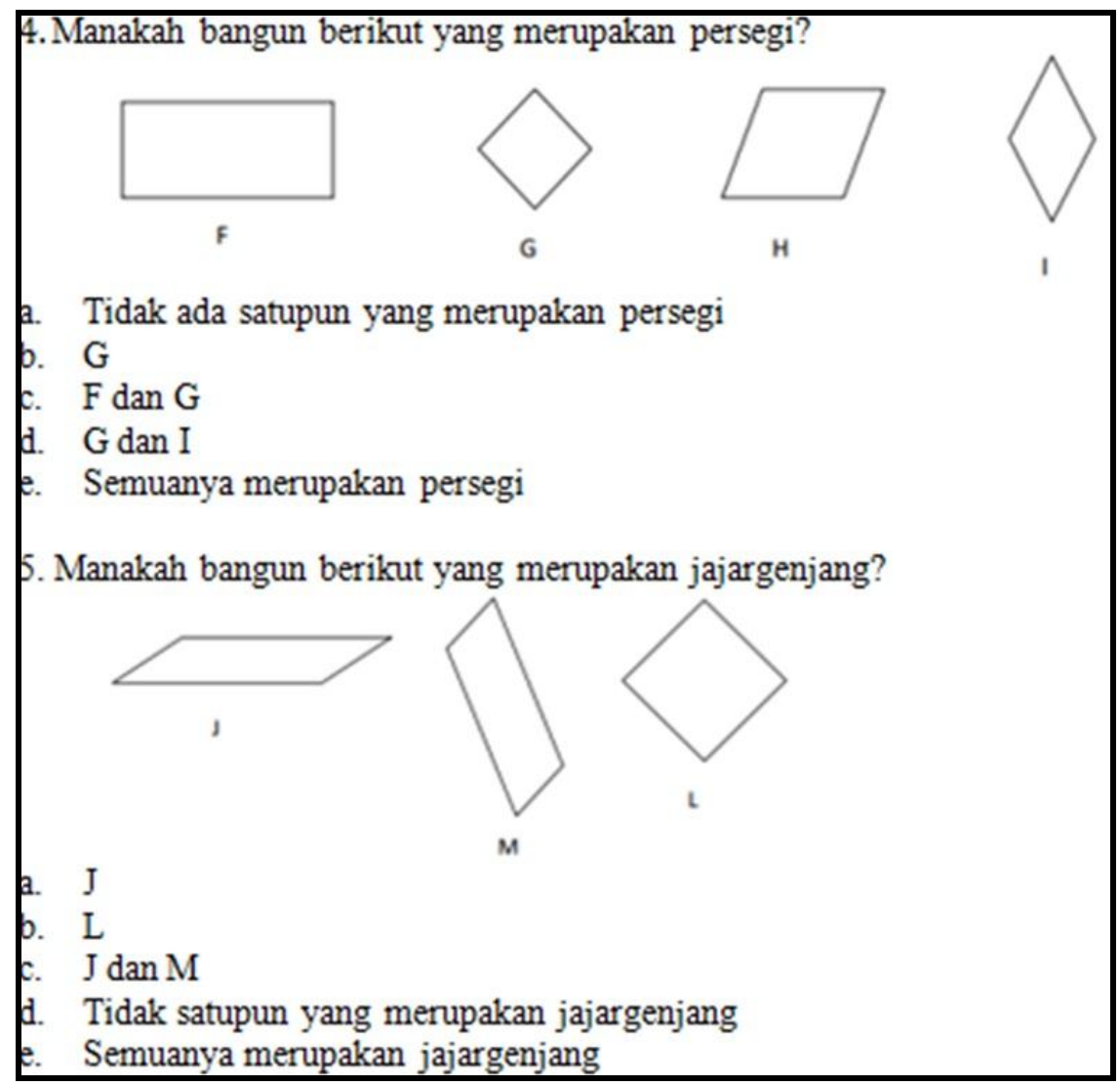

(a)

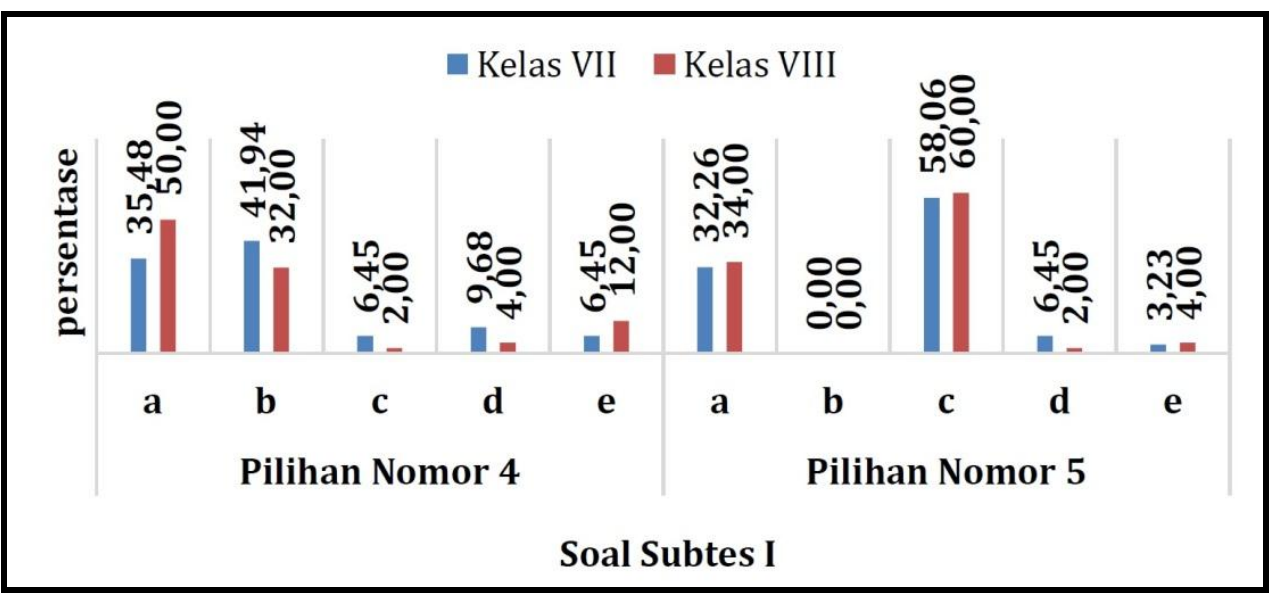

(b)

Gambar 3.(a) Soal nomor 4 dan 5 tes VHGT dan (b) persentase jawaban soal nomor 4 dan 5

Ketidakmampuan siswa dalam mengklasifikasikan juga dapat ditemukan pada saat tes tulis wawancara dalam mendaftarkan jenis-jenis segiempat. Hasil tes

Alifmatika: Jurnal Pendidikan dan Pembelajaran Matematika, Desember 2021, Vol. 3, No. 2 
tulis seperti tampak pada gambar 4 menunjukan semua siswa hanya mendaftarkan jenis-jenis segiempat yang terlihat mirip satu sama lain bentuknya. Sebagai contoh pada saat mendaftarkan persegi dan segiempat tampak mereka hanya mendaftarkan nomor 2 dan 7 termasuk persegi dan nomor 6, 9, dan 12 termasuk persegi panjang, padahal nomor 2 dan 7 seharusnya termasuk persegi panjang juga. Siswa melakukan hal serupa dalam mendaftarkan nomor-nomor yang menunjukan jenis-jenis bangun datar berdasarkan kemiripan bentuk satu sama lain. Mereka tidak memasukan persegi ke dalam persegi panjang, persegi panjang ke dalam jajargenjang, sebagian belah ketupat termasuk ke dalam jajargenjang yaitu nomor 2, 3, 7, 8 dan 13, serta tidak memasukan sebagian belah ketupat ke dalam layang-layang yaitu nomor 2, 7, 8 dan 13 .

Setiap siswa yang telah diwawancarai, mereka mendaftarkan jenis bangun datar berdasarkan prototipe yang sering mereka temui atau yang sering dijadikan contoh. Hasil ini juga ditemukan pada penelitian sebelumnya, bahwa siswa terpengaruh prototipe dan tidak mampu memahami konsep hubungan sifat-sifat antara jenis-jenis segiempat (Sulistiowati, D. L., Herman, T., \& Jupri, 2018; Vinner \& Hershkowitz, 1983). Seperti mereka tidak menggolongkan persegi ke dalam persegi panjang, persegi panjang dan persegi ke dalam jajargenjang, sebagian dari layang-layang dan belah ketupat termasuk ke dalam jajargenjang, dan sebagian dari layang-layang merupakan belah ketupat. Seperti yang terlihat pada gambar 4 (hasil tes tulis dalam mendaftarkan jenis-jenis segiempat), siswa mendaftarkan dengan benar namun masih terpengaruh oleh gambar yang mereka kenal atau oleh prototipe jenis-jenis segiempat.

1. Perhatikan gambar di bawah ini.

Tentukanlah yang termasuk persegi, persegi panjang, jajargenjang, belah ketupat, dan trapesium dengan cara mendaftarkannya nomor gambar pada isian di bawah ini. Kamu dapat menandai lebih dari satu untuk satu bangun datar.
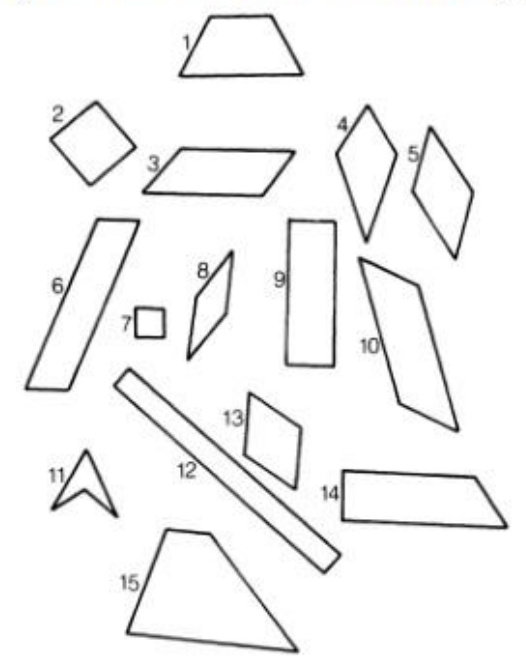

a. Persegi yaitu nomor: ...

b. Persegi panjang yaitu nomor: ...

c. Jajargenjang yaitu nomor: ...

d. Belah Ketupat yaitu nomor:..

e. Layang-layang yaitu nomor:...

f. Trapesium yaitu nomor:..

(a)

Alifmatika: Jurnal Pendidikan dan Pembelajaran Matematika, Desember 2021, Vol. 3, No. 2 


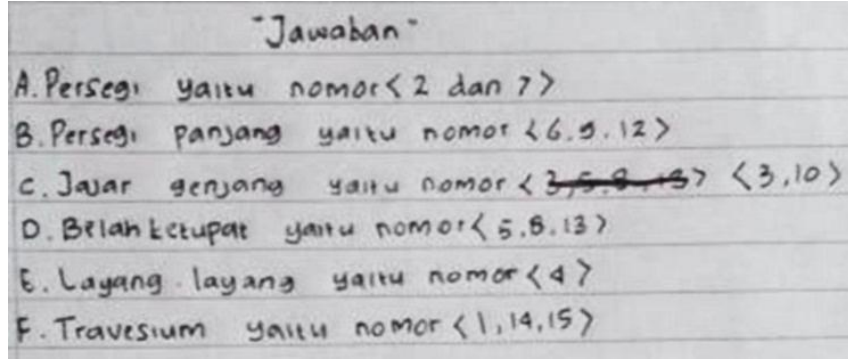

(b)

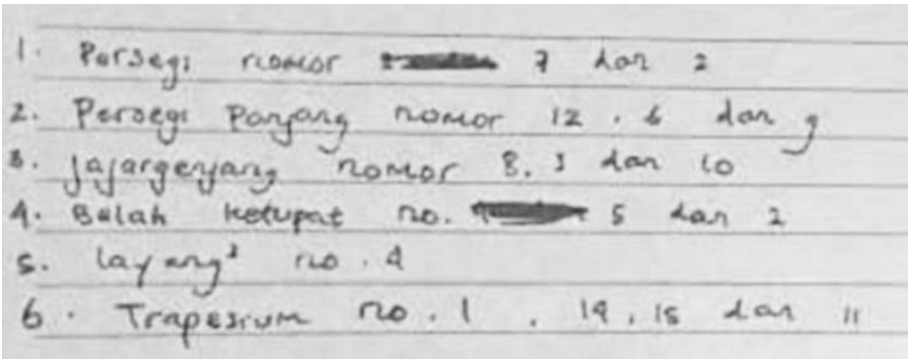

(d)

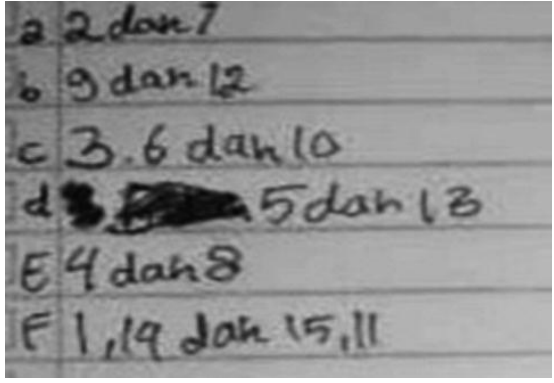

(c)

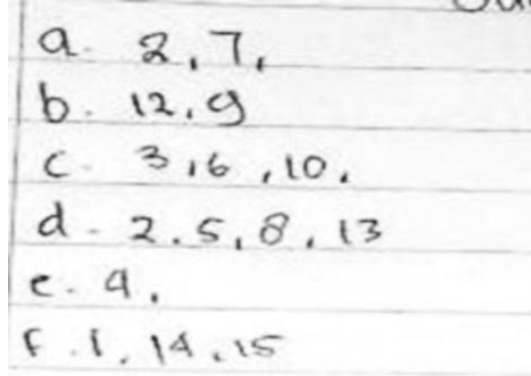

Gambar 4.(a) Soal Tes Tulis Mendaftarkan Jenis-Jenis Segiempat, (b) dan (c) masing-asing Jawaban Tes Tulis Siswa 7S0R2 dan Siswa 7S0S2, dan (d) dan (e) Jawaban Tes Tulis Siswa 8S0R1 dan Siswa 8S0S2

Dalam mendefinisikan siswa level 0 untuk semua kategori baik kelas VII dan kelas VIII mereka belum mampu mendefinisikan secara formal. De Villiers (Michael De Villiers, 2010) mengategorikan siswa ini sebagai orang yang mendefinisikan secara visual. Mereka dalam mendefinisikan masih dipengaruhi oleh bentuk segiempat yang dijadikan prototipe oleh mereka. Prototipe itu mengacu pada ukuran sudut, sisi atau keduanya. Hasil penelitian sebelumnya (Burger \& Shaughnessy, 1986; M De Villiers, 1994; Fujita \& Jones, 2007; Monaghan, 2000) juga mengunjukkan bahwa siswa mengalami kesulitan dalam mendefinisikan secara formal dan terpengaruh oleh gambaran mereka sendiri mengenai suatu bentuk jenis segiempat. Seperti siswa 7S0R2, 7S0S2, dan 8S0R1 mempunyai kesamaan dalam mendefinisikan persegi panjang sebagai segiempat yang mempunyai sepasang sisi yang ukuran panjangnya berbeda. Masing-masing dari mereka mendefinisikan "2 sisinya pendek dan 2 sisinya panjang", "persegi panjang mempunyai 4 sisi dengan 2 pasang sisi yang sama" dan "saya jelaskan bahwa semua bangun yang memiliki panjang dan lebar yang beda itu berarti disebut dengan persegi panjang". Hasil yang sama juga diperoleh oleh Fujita (Fujita, 2012) yang menemukan bahwa banyak pelajar mendefinisikan persegi panjang sebagai segiempat yang mempunyai 2 sisi panjang dan 2 sisi pendek.

Siswa dalam mendefinisikan jajargenjang kurang tepat atau berlebihan, mereka mendefinisikan jajargenjang sebagai segiempat yang mempunyai sepasang sisi sejajar dan sudut-sudut yang berhadapan sama besar. Walaupun mereka menyebutkan dengan benar definisi suatu jenis segiempat, mereka tidak memahami maksud dari definisi tersebut. Ini bisa terlihat dalam wawancara mengklasifikasikan, ketika ditanyai misal mengenai mengapa persegi termasuk ke dalam jajargenjang. Sedangkan 8S0R1 yang salah dalam mendefinisikan

Alifmatika: Jurnal Pendidikan dan Pembelajaran Matematika, Desember 2021, Vol. 3, No. 2 
jajargenjang, yang mendefinisikannya sebagai jenis segiempat yang bentuknya seperti persegi namun tidak simetris dan cenderung miring.

Pewawancara : :Bagaimana cara kamu menggolongkan atau mendaftarkan jenis-jenis bangun datar tersebut?"

8S0R1 : "Dilihat dari bentuk bentuknya. jika bentuk nya sama seperti jenis yang ditanyakan maka bangun datar tersebut termasuk ke dalam jenis tersebut"

8S0S2 :Dengan menyamakan ciri dan definisi bangun tersebut"

Pewawancara : "Apa yang akan kamu jelaskan kepada orang lain supaya mereka dapat menemukan semua jajargenjang pada gambar di atas (misal memberikan pengertian jajargenjang agar orang lain bisa menemukan jajargenjang pada soal nomor 1)?"

8S0R1

: "Saya jelaskan bahwa jajar genjang adalah bangun yang bentuknya seperti persegi namun tidak simetris dan cenderung miring. maka semua bangun yg bentuknya seper ti itu disebut dengan jajargenjang"

8S0S2 : "Jajargenjang adalah bangun datar dua dimensi yang dibentuk oleh dua pasang rusuk yang masing-masing sama panjang dan sejajar dengan pasangannya, dan memiliki dua pasang sudut yang masing-masing sama besar dengan sudut di hadapannya"

Pewawancara : :Kamu telah mendaftarkan bahwa yang termasukjajargenjang adalah nomor 3, 10. Apakah nomor 2 bukan jajargenjang? Jelaskan alasanmu!"

8S0R1

: "karena tidak terlihat seperti jajargenjang"

8S0S2

: "Iya, jajargenjang dengan empat rusuk yang sama panjang disebut belah ketupat"

Berdasarkan banyaknya kesalahan pada nomor 4 dan 5 pada tes geometri van Hiele. Kesalahan dalam menjawab nomor 4 dan 5 pada tes VHGT juga ditemukan pada penelitian Lestriyani (Lestriyani, 2013). Kesalahan ini bisa dilihat dari bagaimana mereka mengklasifikasikan persegi, persegi panjang, dan jajargenjang. Dalam mengklasifikasikan mereka tidak mampu memahami hubungan antara atribut atau sifat-sifat dan definisi yang dimiliki antara jenis segiempat. Mereka memandangnya sebagai sifat yang ekskusif dimiliki oleh jenis segiempat tertentu. Penelitian sebelumnya juga (Michael De Villiers, 2010; Muhassanah, Nur'aini., Sujadi, Imam., 2014; Sulistiowati, D. L., Herman, T., \& Jupri, 2018) menunjukkan bahwa siswa level 0 dan level 1 cenderung memahami definisi jenis segiempat secara parsial, dengan kata lain tidak terdapat hubungan antara keduanya.

Siswa pada level ini tidak memasukan persegi sebagai persegi panjang dengan alasan persegi mempunyai empat sisi yang sama, sedangkan persegi panjang mempunyai dua pasang sisi yang panjang dan pendek. Permasalahan ini

Alifmatika: Jurnal Pendidikan dan Pembelajaran Matematika, Desember 2021, Vol. 3, No. 2 
juga sama ditemukan dalam penelitian de Villiers (Michael De Villiers, 2010) dan Fujita (Fujita, 2012). Alasan yang sama juga digunakan ketika tidak memasukan persegi dan persegi panjang ke dalam jajargenjang. Meskipun mereka mendefinisikan jajagenjang dengan segiempat yang mempunyai sepasang sisi sejajar dan sama panjang dan sudut yang berhadapan sama besar, mereka tidak memahami bahwa sisi-sisi pada persegi dan persegi panjang juga sejajar dan sama panjang.

\section{KESIMPULAN DAN SARAN}

Berdasarkan penelitian menunjukan vahwa siswa level 0 kelas VII dan VIII baik yang berkategori rendah dan sedang diperoleh bahwa dalam mengidentifikasi berdasarkan pada bentuk dan posisi yang telah dia kenali dan membandingkannya dengan bangun datar yang ada, selain itu melihat dari atribut sudut dan sisi yang dipandang secara eksklusif dimiliki oleh suatu jenis bangun datar tertentu.Siswa level 0 dalam mendefinisikan masih dipengaruhi oleh bentuk segiempat yang dijadikan prototipe atau gambaran mereka sendiri mengenai suatu bentuk jenis segiempat. Prototipe ini mengacu pada salah satu ukuran sudut, sisi-sisi, atau keduanya. Terakhir siswa level 0 memahami definisi atau sifat-sifat yang dimiliki secara parsial, dengan kata lain tidak terdapat hubungan antara sifat-sifat suatu jenis segiempat dengan yang lainnya. Bila salah satu sifat dari jenis segiempat berbeda dengan sifat jenis segiempat lainnya, mereka memandangnya sebagai jenis yang berbeda. Dengan kata lain siswa level 0 belum mampu mengklasifikasikan segiempat.

Peneliti memberikan saran untuk penelitian selanjutnya yaitu melakukan wawancara kepada siswa level 0 terhadap kesulitan mereka dalam menjawab soal tes VHGT yang sulit berdasarkan hasil analisis jawaban soal. Wawancara ini dapat menambahkan data mengenai proses berpikir geometri siswa. Peneliti juga memberikan saran untuk para pendidik agar mengajar siswa level 0 dengan berbagai bentuk dan orientasi bangun datar segiempat, serta mengajarkan konsep geometri yang benar. Seperti mengajarkan konsep kesejajaran garis, sudut-sudut yang berhadapan, sudut sehadap, dan lain-lain. Pengajaran konsep yang benar sangat penting ketika mereka mengenal bentuk bukan berdasarkan tampilan secara visual, seperti kemiringan garis, sudut tumpul dan lancip, satu sisinya panjang dan yang lainnya panjang, dan lain-lain.

\section{UCAPAN TERIMA KASIH}

Terima kasih kepada para pembimbing penelitian ini yaitu Dr. Dadang Juandi, M.Si dan Al Jupri, S.Pd., M.Sc., P.hD yang telah memberikan arahan dan saran selama penelitian saya. Penelitian ini resmi menggunakan dana dari peneliti pertama. Terima kasih juga untuk kepala sekolah dan murid-murid dari kedua sekolah penelitian. 


\section{DAFTAR PUSTAKA}

Burger, W. F., \& Shaughnessy, J. M. (1986). Characterizing the van Hiele Levels of Development in Geometry. Journal for Research in Mathematics Education, 17(1), 31-48.

Crowley, M. L. (1987). The van Hiele Model of the Development of Geometric Thought. In Learning and Teaching Gemretry, K-12, (pp. 1-16). National Council of Teachers of Mathematics.

De Villiers, M. (1994). The role and function of a hierarchical classification of quadrilaterals. For the Learning of Mathematics, 14(1), 11-18.

De Villiers, M. (2010). Some Reflections on the Van Hiele theory. The 4th Congress of Teachers of Mathematics of the Croatian Mathematical Society. https://www.researchgate.net/publication/264495589

De Villiers, M. (1996). The Future of Secondary School Geometry Michael de Villiers. The SOSI Geometry Imperfect Conference, 2-4 October.

Fischbein, E. (1993). The Theory of Figural Concepts Abstract. Educational Studies in Mathematics, 24(2), 139-162.

Fujita, T. (2012). Learners' level of understanding of the inclusion relations of quadrilaterals and prototype phenomenon. Journal of Mathematical Behavior, 31(1), 60-72. https://doi.org/10.1016/j.jmathb.2011.08.003

Fujita, T., \& Jones, K. (2007). Learners' understanding of the definitions and hierarchical classification of quadrilaterals: Towards a theoretical framing. Research in Mathematics Education, 9(1), 3-20. https://doi.org/10.1080/14794800008520167

Fuys, D., Geddes, D., \& Tischler, R. (1988). The Van Hiele Model of Thinking in Geometry among Adolescents. Journal for Research in Mathematics Education. Monograph, 3, i - 196.

Gutiérrez, A., \& Jaime, A. (1998). On the Assessment of the Van Hiele Levels of Reasoning. Focus on Learning Problems in Mathematics Spring \& Summer Edition, 20(2 \& 3), 27-46.

Gutiérrez, Angel., Jaime, Adela ., \& Fortuny, J. M. (1991). An Alternative Paradigm to Evaluate The Acquisition Acquisition of The Van Hiele Levels. Journal for Research in Mathematics Education, 22(3), 237-251.

Hershkowitz, R. (1998). Reasoning in Geometry. In: Mammana C., Villani V. (eds) Perspectives on the Teaching of Geometry for the 21st Century. New ICMI Study Series, 5, 29-83.

Ho, S. . (2003). Young children's concept of shape: van Hiele Visualization Level of geometric thinking. The Mathematics Educator, 7(2), 71-85.

Lestriyani, S. (2013). Identifikasi Tahap Berpikir Geometri Siswa SMP Negeri 2 Ambarawa Berdasarkan Teori Van Hiele. Universitas Kristen Satya Wacana.

Linda, L., Bernard, M., \& Fitriani, N. (2020). Analisis Kesulitan Siswa SMP Kelas VIII pada Materi Segiempat dan Segitiga Berdasarkan Tahapan Berpikir van Hiele.

Alifmatika: Jurnal Pendidikan dan Pembelajaran Matematika, Desember 2021, Vol. 3, No. 2 
Ournal of Medives: Journal of Mathematics Education IKIP Veteran Semarang, $4(2), 233-242$.

Mariotti, M. A. (1992). Geometrical reasoning as a dialectic between the figural and the conceptual aspects. Structural Topology 1992 Núm 18.

Monaghan, F. (2000). What difference does it make? Children's views of the differences between some quadrilaterals. Educational Studies in Mathematics, 42(2), 179-196.

Muhassanah, Nur'aini., Sujadi, Imam., \& R. (2014). Analisis Keterampilan Geometri Siswa dalam Memecahkan Masalah Geometri Berdasarkan Tingkat Berpikir Van Hiele. Jurnal Elektronik Pembelajaran Matematika, 2(1), 54-66.

Nopriana, T. (2013). Penerapan Model Pembelajaran Geometri Van Hiele Sebagai Upaya Meningkatkan Kemampuan Berpikir Geometri dan Disposisi Matematis pada Siswa SMP. Universitas Pendidikan Indonesia.

Okazaki, M., \& Fujita, T. (2007). Prototype phenomena and common cognitive paths in the understanding of the inclusion relations between quadrilaterals in Japan and Scotland. Proceedings of the 31st Conference of the International Group for the Psychology of Mathematics Education, 41-48.

Rahmat, T. (2019). Proses Berpikir Mahasiswa Pendidikan Matematika IAIN Bukittinggi. Math Educa Journal, 3(1), 98-108.

Sulistiowati, D. L., Herman, T., \& Jupri, A. (2018). Students' Geometry Skills Viewed from Van Hiele Thinking Leve. 5th ICRIEMS Proceedings, 55-62.

Tirtaprimasyah, H. P. S., \& Susanto, N. Y. (2015). Analisis Proses Berpikir Siswa Pada Pembelajaran Geometri Kelas X SMA Berdasarkan Teori Van Hiele Berbasis Scientific Approach. Seminar Nasional Matematika dan Pendidikan Matematika UNY 2015, 567-574.

Usiskin, Z. (2008). The classification of Quadrilateral: a Study in DefinitioThe classification of Quadrilateral: a Study in Definitionn. Information Age Publishing.

van De Walle, J. A., Karp, K. S., \& Bay-Williams, J. (2016). Elementary and Middle School Mathematics, Teaching Developmentally. Pearson Education.

Vinner, S., \& Hershkowitz, R. (1983). On concept formation in geometry. https://www.researchgate.net/publication/284382026

Vinner, S., \& Hershkowitz, R. (1980). Concept images and common cognitive paths in the development of some simple geometrical concepts. Proceedings of the Fourth International Conference for the Psychology of Mathematics Education, 177-184. 